\title{
Estimating the wage penalty for maternal leave
}

Citation for published version (APA):

Buligescu, B., de Crombrugghe, D. P. I., Mentesoglu, G., \& Montizaan, R. M. (2008). Estimating the wage penalty for maternal leave. ROA. ROA Research Memoranda No. 005

https://doi.org/10.26481/umaror.2008005

Document status and date:

Published: 01/01/2008

DOI:

10.26481/umaror.2008005

Document Version:

Publisher's PDF, also known as Version of record

\section{Please check the document version of this publication:}

- A submitted manuscript is the version of the article upon submission and before peer-review. There can be important differences between the submitted version and the official published version of record.

People interested in the research are advised to contact the author for the final version of the publication, or visit the DOI to the publisher's website.

- The final author version and the galley proof are versions of the publication after peer review.

- The final published version features the final layout of the paper including the volume, issue and page numbers.

Link to publication

\footnotetext{
General rights rights.

- You may freely distribute the URL identifying the publication in the public portal. please follow below link for the End User Agreement:

www.umlib.nl/taverne-license

Take down policy

If you believe that this document breaches copyright please contact us at:

repository@maastrichtuniversity.nl

providing details and we will investigate your claim.
}

Copyright and moral rights for the publications made accessible in the public portal are retained by the authors and/or other copyright owners and it is a condition of accessing publications that users recognise and abide by the legal requirements associated with these

- Users may download and print one copy of any publication from the public portal for the purpose of private study or research.

- You may not further distribute the material or use it for any profit-making activity or commercial gain

If the publication is distributed under the terms of Article $25 \mathrm{fa}$ of the Dutch Copyright Act, indicated by the "Taverne" license above, 


\title{
Estimating the wage penalty for maternal leave
}

\author{
Bianca Buligescu \\ Denis de Crombrugghe \\ Gülçin Menteşoğlu \\ Raymond Montizaan
}

ROA-RM-2008/5

June 08

Research Centre for Education

and the Labour Market

P.O. Box 616

6200 MD Maastricht

The Netherlands

E-mail: secretary@roa.unimaas.nl

Internet: www.roa.unimaas.nl

Maastricht University

Faculty of Economics and Business Administration 
The ROA Research Memorandum Series was created in order to make research results available for discussion, before those results are submitted for publication in journals. 
ROA-RM-2008/5 » http://www.roa.unimaas.nl/resmem.htm

\section{Abstract}

\section{Estimating the wage penalty for maternal leave ${ }^{1}$}

The focus of this paper is the size of the wage penalty due to maternal leave incurred by working mothers in Germany. Existing estimates suggest two-digit penalties of up to 30 percent, with very little rebound over time. We apply recent panel data methods designed to address problems of sample selectivity, unobserved heterogeneity and endogeneity to German Socio-Economic Panel (GSOEP) data. The selectivity issue arises because no wage is observed for employees who are on leave. Heterogeneity takes the form of unobserved individual effects correlated with explanatory variables. Endogeneity is due to the simultaneity of the wage and participation outcomes. Heckman's classic treatment of selectivity requires extensions to deal with both heterogeneity and simultaneity. We present an extension for the case of a censored tobit participation model and use it to exploit the actual working hours data available in GSOEP. We also investigate the sensitivity of the results to the choice of method. Our estimates imply a wage penalty due to maternal leave which although substantial remains below previous estimates. Furthermore, we find that this penalty is less persistent than other studies suggest. Five years after the career interruption mothers seem to have caught up.

Key-words: maternal leave, wage penalty, tobit selection, GSOEP.

1. The authors are all affiliated with Maastricht University, the Netherlands. Buligescu is with the Maastricht Graduate School of Governance; de Crombrugghe and Menteşoğlu are with the Faculty of Economics and Business Administration; Montizaan is with the Research Centre for Education and the Labour Market (ROA). We wish to thank Lex Borghans, Charlotte Büchner, Kathrin Goeggel, Bart Goldsteyn, Andries de Grip, Ben Kriechel, Jan Sauermann, Sybrand Schim van der Loeff, Maarten Vendrik and participants at the LOWER conference in Volos, September 2007, as well as two anonymous referees for their helpful comments and suggestions. Corresponding author: r.montizaan@roa.unimaas.nl. 
Bianca Buligescu

Maastricht Graduate School of Governance P.O. Box 616

6200 MD Maastricht

The Netherlands

bianca.buligescu@governance.unimaas.nl

Gülçin Menteşoğlu

FdEWB

P.O. Box 616

6200 MD Maastricht

The Netherlands

g.mentesoglu@algec.unimaas.nl
Denis de Crombrugghe

FdEWB

P.O. Box 616

6200 MD Maastricht

The Netherlands

d.decrombrugghe@ke.unimaas.nl

Raymond Montizaan

ROA

P.O. Box 616

6200 MD Maastricht

The Netherlands

r.montizaan@roa.unimaas.nl 


\section{Introduction}

Since Mincer and Polachek's (1974) seminal paper on the earnings of women, the wage penalties for family related career breaks have been investigated with different data and methods leading to a variety of estimates. Some obvious explanations for the differences between estimates are differences or changes in local conditions, such as institutional, legal, economic and cultural circumstances, and the selection of indirect effects and controls included. However, part of the differences is to be explained by the way problems such as sample selectivity, unobserved heterogeneity and endogeneity have been dealt with. This paper contributes to the literature by analyzing the wage penalty for maternal leave with recent panel data methods that simultaneously account for all three problems. Using data for the period 1994-2005 from the German Socio-Economic Panel (GSOEP), and building on methodological advancements by Wooldridge (1995) and Semykina and Wooldridge (2006), we investigate the size of the wage penalty for maternal leave and its sensitivity to the method used.

The mainstream approach to the sample selectivity problem in wage equations is due to Heckman $(1976,1979)$. Previous studies that follow this approach typically use a probit selection equation to model labour market participation and from it derive inverse Mills ratios to serve as correction terms in the earnings function. However, the choice faced by mothers is not just whether or not to work, but also whether to take on a fulltime or a part-time job, and more specifically how many hours to work. We can use more information if we explicitly model women's decision about the extent of participation and use that to correct for selectivity in a wage equation. The extent of participation is measured in GSOEP by the actual working hours of respondents (although they only 
report it for one week). Since the choice of working hours is naturally limited we specify it as a censored tobit process. An outcome limited by bounds is obviously more informative than a binary outcome and the tobit specification should therefore be more efficient in terms of data usage than a probit or logit one. Because the choice of working hours is explicitly made within the model, working hours will be treated as an endogenous regressor in the wage equation.

In the context of panel data, the tobit specification shares with the probit specification a difficult technical complication. Heterogeneity, in the standard form of unobserved individual effects, causes an incidental parameters problem which undermines the consistency of Fixed Effects (FE) estimators. ${ }^{1}$ Semykina and Wooldridge (2006) have proposed to circumvent the incidental parameters problem in a probit selection model by modelling the unobserved individual effects as linear functions of appropriate instrumental variables or time averages, following ideas of Mundlak (1978) and Chamberlain (1980). ${ }^{2}$ In this paper, we follow the Semykina-Wooldridge proposal but adapt it to the case of the censored tobit (rather than probit) participation model.

We use here the term maternal leave to cover both the legally mandatory break around maternity (called maternity protection) and additional time off work taken by a

\footnotetext{
${ }^{1}$ This is because every new panel member comes with a new "parameter", the unobserved individual effect, and even if the panel size is increased in the cross-sectional dimension, information does not accumulate about individual effects. The usual, FE approach is to eliminate incidental parameters by a clever data transformation, but in nonlinear models like the probit and tobit selection models this is not generally possible. The standard Random Effects (RE) approach avoids the incidental parameters problem altogether at the cost of assuming independence (more precisely uncorrelatedness) between the unobserved effects and all observed explanatory variables - a radical assumption that is untenable in our application and that must be avoided.

${ }^{2}$ For the case of probit-based selectivity in panel data, Kyriazidou (1997) and Rochina-Barrachina (1999) propose alternative corrections based on pairwise differencing of observations; for a thorough discussion and comparison of these methods, see Dustmann and Rochina-Barrachina (2007). Different approaches based on the imputation of potential wages for subjects not in work are explored by Olivetti and Petrongolo (2006).
} 
mother to look after her child in the framework of German parental leave legislation. We use the term maternal leave wage penalty in the limitative sense of the partial or direct effect of maternal leave on wages as distinct from a reduction in working hours, foregone experience, or lost tenure, which are observable separately. The overall wage disadvantage of mothers, combining direct and indirect effects, is variously known in the literature as motherhood wage penalty, child penalty or family gap (Waldfogel 1998, Budig and England 2001, Simonsen and Skipper 2006).

Several possible explanations can be found in the literature for wage penalties related to motherhood, such as discrimination, job matching, human capital theory and signalling. The first two are of little relevance for the specific case of maternal leave. ${ }^{3}$ By far the most widely quoted explanation which directly applies to maternal leave comes from human capital theory. Maternal leave may lead to a decrease in wages as a consequence of human capital depreciation (Mincer and Polachek 1974; Mincer and Ofek 1982). ${ }^{4}$ The standard economic model of wage growth and career interruptions assumes that workers are paid according to their productivity which is in turn determined by the accumulation of human capital. During career interruptions individuals not only cease to accumulate experience but also face human capital deterioration due to non-use or atrophy of their human capital stock. The ensuing decrease in productivity could explain

\footnotetext{
${ }^{3}$ The discrimination approach suggests that employers pay lower wages to mothers because they assume that mothers put less effort in the job (Waldfogel 1998). Therefore, the focus is on the presence of children instead of on career interruptions. The matching approach explains the wage penalty by the loss of the rents of a good match when highly skilled women who get children interrupt their careers (Anderson et al. 2002). However, jobs of mothers who are on maternal leave are protected by legislation which means they can return to the same job they had before the career interruption.

${ }^{4}$ A reverse channel of causality has also been considered in the literature which emphasizes that women who earn a low wage could select themselves into child-bearing; see Lundberg and Rose (2000) for the US, and Kunze and Ejrnaes (2004) for Germany.
} 
a decrease in wages. ${ }^{5}$ This decrease in wages may not be entirely irreversible in theory. Mincer and Ofek (1982) distinguish between short and long run effects. The rate of net investment in human capital is likely to accelerate in the period directly following an interruption in order to restore the loss incurred. Hence the wage penalty would be higher immediately after a career interruption than in later years.

A second explanation for the maternal leave wage penalty might come from the signalling approach. This approach links the wage penalty to the length of the career break, considering that longer periods spent in parental leave would signal a woman's character with respect to career commitment for potential employers (Albrecht et al. 1999).

Compared to the extensive literature on the motherhood wage penalty, the component of the penalty due specifically to maternal leave has been less extensively researched. ${ }^{6}$ In order to analyse its magnitude and persistence, it is necessary to distinguish the different possible types of career interruptions: periods out of the labour market, periods spent in parental leave, periods of unemployment, military service, other activity or diverse. For Sweden, Albrecht et al. (1999) measure the accumulated duration in months of the aforementioned career breaks. They find only a relatively small penalty due to parental leave $(0.15 \%$ per month of interruption), or household time $(0.13 \%)$, whereas the penalty due to unemployment is significantly higher $(0.37 \%)$. The fact that

\footnotetext{
${ }^{5}$ In addition, Mincer and Ofek (1982) argue that wages could also be affected by less investment in training during the pre-interruption periods as workers anticipate the career break. A complementary explanation may be that mothers upon return to work change jobs or firms and therefore the wage penalty is also partly due to firm specific human capital loss (Kunze 2002).

6 Estimates of the motherhood wage penalty range between 3 to $7 \%$ for one child, 9 to $13 \%$ for two or more children for the US (Waldfogel 1998, Harkness and Waldfogel 2003, Budig and England 2001, Amuedo-Dorantes and Kimmel 2005); 2 to $9 \%$ for one child, 12 to $25 \%$ for two or more children for the UK (Harkness and Waldfogel 2003, Davies and Pierre 2005); 2 to $4 \%$ for one child, 11 to $12 \%$ for two or more children for Germany (Harkness and Waldfogel 2003, Davies and Pierre 2005).
} 
parental leave and household time result in similar effects on wages is interpreted as evidence in favour of women's human capital depreciation.

Most studies of German data find a large and significant negative effect of maternal leave on women's wage rates. Kunze (2002) investigates wage penalties in a sample of full-time skilled workers highly attached to the labour market who are followed during their early career. She differentiates between parental leave (including the "maternity protection" period), and other career breaks, such as unemployment, national service and non-working. The effect of career interruptions is measured using dummy variables for the occurrence of career interruptions in each of the previous six years or more. She finds a wage penalty of more than $18 \%$ for a parental leave interruption in the previous year and $4.75 \%$ for time out of the labour market, after correcting for individual effects. The effect is found to be quite persisitent through time for parental leave interruptions (still 13\% after five years) whereas the penalty for time out of the labour market seems to fade away after four years. Beblo and Wolf (2002) also distinguish among various types of career breaks: parental leave (including the “maternity protection” period), unemployment, training and military service, and periods out of the labour force. These are measured as the fraction of time spent in a certain state in each of the previous ten years or more. However, they find no significant penalty for parental leave whereas for being out of the labour force they find a sizable wage penalty of $5 \%$ to $8 \%$.

The latest studies for Germany use treatment effects evaluation to control for selection into motherhood. Kunze and Ejrnaes (2004) study the evolution of women's wages in Germany around the birth of their first child and use matching to construct a 
comparison group with similar labour market characteristics. They instrument experience, unemployment and parental leave. ${ }^{7}$ They report that new mothers returning to work suffer a drop in wages of about 10 to 20 percent and that women who remain childless have different wage and labour market processes than mothers. Beblo, Bender and Wolf (2006) use another matching strategy and create a control group of women who have been continuously employed by the same firm, and have the same probability of becoming a mother. Using conditional difference in difference estimation and matching methods, they find a large penalty for child related career interruptions of 25 to $30 \%$ of the daily wage one year after reentry. This gap diminishes when they control for firmspecific effects, suggesting that women anticipating motherhood select firms imposing low maternal leave penalties.

In line with the existing literature, we distinguish between different types of career interruptions as well as between short term and delayed effects of maternal leave on wages. From the GSOEP data files covering 1994 through 2005, we calculate the time share of maternal leave in the five calendar years preceding each wave and include these in the wage equation for working mothers. The rationale is that the time share of interruptions in the immediately preceding year will capture the direct short term effect of maternal leave, whereas the share of interruptions in earlier years ( $t-2$ until $t-5)$ will capture delayed effects. We also control for the number of children and for other types of career interruptions in the last five years. We find robust evidence of a substantial wage penalty in the first year following maternal leave which ranges between 6 and 14 percent,

\footnotetext{
7 The instruments used by Kunze and Ejrnaes (2004) were lagged levels of work experience, work experience squared, unemployment, age at entry into the labour market, and first differences in potential experience. Parental leave is instrumented with changes in the parental leave system and the availability of child care facilities in the region. Unemployment is instrumented with the regional unemployment rate.
} 
which is not nearly as high as some previous estimates. In subsequent years the maternal leave penalty is apparently made up for, although there is a resurgence in the fourth year possibly due to late returners. In the fifth year following maternity there seems to be no direct maternal leave effect left. The effect of non-maternal interruptions seems to dwindle after three years.

Our estimation results confirm the existence of selectivity, heterogeneity and endogeneity biases. In particular, accounting for the endogeneity of actual working hours practically doubles the estimated wage penalties and reverses the relationship between the wage rate and the number of hours worked.

The paper is organized as follows. In the next section we briefly discuss the maternity and parental leave system in Germany. Section 3 introduces our econometric model. The GSOEP data set used is described in Section 4. Results are presented in Section 5 and concluding remarks in Section 6.

\section{German Maternal Leave Legislation}

The traditional German parental leave policy is based on the "breadwinner model" which assumes that the mother stays at home to provide child care while the father works to provide the family income. As times are changing, it becomes increasingly acceptable and desirable for women with young children to work as well. The current model may therefore be described as the "one and a half earner model" in which the father works full-time and the mother has a part-time job (Spiess and Wrohlich, 2006). The preference for a part-time job must be seen in the context of a limited supply of day care centres for children below three years. Especially in the Western part of Germany it is hard to get 
day care for young children, which complicates the combination of a full-time job with child $^{\text {care. }}{ }^{8}$

In Germany, the rights of young mothers as well as fathers are protected by maternal leave legislation which is based on the "Bundeserziehungsgeldgesetz" ("childrearing benefit law”) enacted in 1986 and extended several times since. Under the current maternal leave legislation it is compulsory for pregnant women to take leave for a “maternity protection” period of six weeks before the estimated birth date and eight weeks after child delivery. During this period work is prohibited. The maternal leave legalisation further includes maternity benefits which are provided to full-time and parttime working parents, but also to non-working and unemployed parents if the annual income is below a certain limit. The parent, usually the mother, who stays at home is entitled to receive the benefit regardless of her employment status in the first six months, although the benefits are lower for parents who do not work full-time. After the first six months the benefit is scaled down and becomes means-tested, and it is maintained for a maximum duration of 24 months.

Following up on the compulsory “maternity protection” period, mothers and fathers are entitled to job-protected parental leave for an extended period of up to 34 months. ${ }^{9}$ This means that both mothers and fathers have the right to return to a job that is comparable to the one held before birth within the same firm. If the parent returns within one year, he or she has the right to return to exactly the same work place as before. Firms

\footnotetext{
${ }^{8}$ Kreyenfeld (2001, p. 44) reports that in Western Germany, less than three percent of children aged 0-3 are in public daycare, against one third of the children in the same age group in former East Germany.

9 During the period of parental leave, the mother or father can work part-time between 15-30 hours per week, unless that would create considerable problems for the company. After parental leave has expired employees can return to work full-time.
} 
are not allowed to dismiss the parent within this time period. However, this does not imply any protection of the wage level. Upon return, firms can pay a lower wage, even if the parent works the same number of hours (Bender et al. 2003).

\section{The econometric model}

Our labour market model for women is based on that of Heckman (1976, 1979). The actual wage rate earned by a woman is determined as the "offer wage" that she can potentially earn on the labour market provided she participates. If she has a higher reservation wage, however, she chooses not to participate and the offer wage remains unobserved. The participation decision is modelled by means of a latent variable measuring the extent of participation, with a reduced-form equation explaining how the extent of participation depends on exogenous variables, and a censoring equation generating corner solution outcomes (zero participation). Formally we specify the following system of equations determining the wage rate $y_{1 i t}$, the latent participation measure $y_{2 i t}^{*}$, and the actual participation measure $y_{2 i t}$ :

$$
\begin{aligned}
& \text { (1) } y_{1 i t}=x_{1 i t}^{\prime} \beta_{1}+\alpha_{1 i}+u_{1 i t} \\
& \text { (2) } y_{2 i t}^{*}=z_{i t}^{\prime} \delta_{2}+\gamma_{2 i}+u_{2 i t} \\
& \text { (3) } y_{2 i t}=\max \left\{0, y_{2 i t}^{*}\right\} .
\end{aligned}
$$

As is conventional, the subscript $i$ refers to a random cross-section of women in their fertile age $(i=1, \ldots, N)$ and the subscript $t$ to a fixed set of calendar years $(t=1994, \ldots$, 2005). The primary dependent variable $y_{1 i t}$ is the logarithm of the hourly wage rate of individual $i$ in year $t$ and is only selectively observed, namely, when the latent 
participation decision $y_{2 i t}^{*}$ is positive. GSOEP respondents report actual working hours for the week preceding the interview and these are taken as selected observations of $y_{2 i t}$ in equation (3). Nonpositive values of $y_{2 i t}^{*}$ are observed as zero values of $y_{2 i t}$, indicating no paid activity took place. The relevant population is restricted to women aged 16 to 45 at the time of entry into the panel, and who are neither students nor self-employed since the motives of the latter with respect to labour market participation are specific.

The system comprises two sets of explanatory variables. In the wage equation, $x_{1 i t}^{\prime}$ is a vector of $K$ variables some of which may be endogenous, with $\beta_{1}$ the corresponding vector of coefficients. The variables in $x_{1 i t}$ include the determinants of both the offer and the reservation wage. In the participation equation, $z_{i t}^{\prime}$ is a vector of $L$ ( $\geq K)$ strictly exogenous variables which can be observed whether or not individual $i$ participates in the labour market, with $\delta_{2}$ the corresponding vector of coefficients. Because endogenous regressors and in particular the wage rate are excluded from it, the participation equation should be interpreted as a reduced-form equation. By the same token, $z_{i t}$ should include all exogenous determinants of the wage rate appearing in $x_{1 i t}$ and not dependent on being a participant, as well as any other available individual or household characteristic possibly affecting the wage rate indirectly.

Equations (1) and (2) both include unobserved heterogeneity in the form of timeconstant individual effects denoted $\alpha_{1 i}$ and $\gamma_{1 i}$. As emphasised by Mundlak (1978), such unobserved individual effects are likely to be related to observed characteristics in $x_{1 i t}$ and $z_{i t}$ rather than independent. The remaining terms $u_{1 i t}$ and $u_{2 i t}$ are "idiosyncratic" 
disturbances, with $u_{1 i t}$ likely to have nonzero conditional expectation due to selective sampling, i.e., wages being observed for labour market participants only. Our model therefore combines problems of panel heterogeneity, endogenous sample selection and endogenous regressors.

To tackle these combined problems we adopt the formal panel data framework of Wooldridge (1995) and Semykina and Wooldridge (2006). In terms of the generality of the assumptions made, this framework presents a number of important advantages for our purposes. First and most recognisably, it disposes with the classical independence assumption on random effects. Specifically, it allows for unobserved effects correlated with observed individual characteristics, à la Mundlak (1978) or Chamberlain (1980), and manages to obtain consistent estimates for the wage equation in spite of the incidental parameter problem affecting the participation equation. Second, while in the crosssectional dimension of the panel the standard assumption of independent sampling is maintained, no assumption of independence over time within panel units is required. Estimates will therefore be robust to serial correlation in the idiosyncratic disturbances $u_{1 i t}$ and $u_{2 i t}$. Thirdly, the assumptions do not require that all explanatory variables in the wage equation are exogenous. Instead, to deal with the potential endogeneity of certain elements of $x_{1 i t}$, it is required that $z_{1 i t}$ can serve as a set of instrumental variables, i.e., that the variables in $z_{1 i t}$ are correlated with those in $x_{1 i t}$ yet strictly exogenous in both equations. The possibility to treat a regressor as endogenous is especially relevant for the number of working hours in the wage equation, which is by design part of the labour market outcome. Previous studies have pointed out that the number of hours worked by women is potentially endogenous with respect to the wage as high earning women might 
decide to work longer hours and interrupt their careers less frequently than women who earn a lower wage (see Lundberg and Rose 2000). ${ }^{10}$

In one respect however, the Semykina-Wooldridge framework does not suffice for our purposes. Whereas in their case the participation decision is observed only in the form of a binary $0 / 1$ indicator ( $d_{i t}=1\left\lfloor y_{2 i t}^{*}>0\right\rfloor$ ), amenable to a probit selection process, here we can partially observe the latent variable $y_{2 i t}^{*}$ (as $y_{2 i t}=d_{i t} y_{2 i t}^{*}$ ). This feature of our data motivates us to extend the existing framework by introducing a selection equation of the tobit type involving a corner solution.

The vulnerability of selection models to unobserved heterogeneity in panel data is well known. The presence of unobserved individual effects causes an incidental parameter problem undermining the consistency results that are the usual justification for FE estimators. This is because every new individual in the panel comes with a new parameter, namely the unobserved effect. In linear models the problem is resolved by a data transformation (either "within" or "first differencing”) designed to eliminate the unobserved effects from the model and the corresponding likelihood function. In nonlinear models such as selection models this is not in general possible The tobit limited choice specification shares this incidental parameters problem with the probit binary choice model. Semykina and Wooldridge (2006) propose to circumvent the incidental parameters problem by formalising the dependency of unobserved individual effects on appropriate instrumental variables or time averages, following the now classic

\footnotetext{
${ }^{10}$ Dustmann and van Soest (1998) reject the hypothesis that working hours are exogenous for the male workers in GSOEP. Arguably, if working hours are endogenous for men, this is even more likely to be the case for women.
} 
approaches of Mundlak (1978) and Chamberlain (1980). We now apply this idea in the context of the censored tobit participation model.

Let us denote time-averages, initial levels or similar time-constant values of the exogenous variables in $z_{i t}$ by so-called "Mundlak terms" $\overline{z_{i}}$. and interpret them as a set of persistent individual features. We can decompose the unobserved individual effects into a systematic part linearly dependent on $\overline{z_{i}}$. and an unexplained remainder term. Splitting both $\alpha_{1 i}$ and $\gamma_{1 i}$ in this way, and introducing some self-explanatory notation, the model is rewritten as the following system of two equations:

$$
\begin{aligned}
& \text { (4) } y_{1 i t}=x_{1 i t}{ }^{\prime} \beta_{1}+\xi_{01}+\overline{z_{i i}}{ }^{\prime} \xi_{1}+\varepsilon_{1 i}+u_{1 i t} \\
& \text { (5) } y_{2 i t}=\max \left\{0, z_{i t}{ }^{\prime} \delta_{2}+\xi_{02}+\overline{z_{i i}}{ }^{\prime} \xi_{2}+\varepsilon_{2 i}+u_{2 i t}\right\} .
\end{aligned}
$$

The composite disturbances in these two equations are likely to be correlated with each other, inasmuch as correlation is likely between the remaining individual effects $\varepsilon_{1 i}$ and $\varepsilon_{2 i}$ as well as between the idiosyncratic disturbances $u_{1 i t}$ and $u_{2 i t}$. To deal with the potential correlation between the composite disturbances, Semykina and Wooldridge propose the following linear conditional expectation assumption: ${ }^{11}$

$$
E\left(\varepsilon_{1 i}+u_{1 i t} \mid \varepsilon_{2 i}+u_{2 i t}, z_{i 1}, \ldots, z_{i T}\right)=\rho_{11 t} \varepsilon_{2 i}+\rho_{12 t} u_{2 i t} .
$$

While this is a formal assumption keeping the model manageable, it still provides flexibility by allowing residual correlation to subsist even after the introduction of the Mundlak terms controlling for persistent individual features in (4) and (5).

In order to estimate the model with standard methods some further parametric assumptions are needed. In particular, the tobit selection model requires normality

\footnotetext{
${ }^{11}$ This corresponds to parts (iii) and (iv) of Assumption 5.1 in Semykina and Wooldridge (2006).
} 
assumptions for the unobserved terms of the participation equation $\varepsilon_{2 i}$ and $u_{2 i t}$ (but not for those of the wage equation). Under these assumptions the participation equation (5) forms a sequence of $T$ cross-sectional censored tobit models, in which all individual effects are absorbed by the disturbances. From each cross-section equation the residuals can be computed, to serve as selectivity correction terms in the wage equation, in the same way that inverse Mills ratios would in a probit-based specification; see, e.g., Wooldridge (1995, 2002). We follow the Wooldridge proposal to make the estimation of the tobit participation equation less restrictive and (arguably) more robust by allowing all its coefficients to be time-varying. In the process of estimating the sequence of censored tobit models we found that the $T$ estimated cross-sectional equations are very similar and that restricting the coefficients to stay constant over time has very little effect on the estimated values. Although we exploit this finding to simplify our presentation of the estimated tobit model in Table 2 below, the selectivity correction terms in the wage equation will be obtained from unrestricted, time-varying estimates.

Turning to the wage equation, Semykina and Wooldridge (2006) formally present a set of conditions under which equation (4) can be consistently estimated in spite of the combined problems of unobserved heterogeneity, sample selectivity, and endogeneity of some of the regressors in $x_{1 i t}$. The proposed consistent estimation procedure is to regress $y_{1 i t}$ on $x_{1 i t}, \overline{z_{i}}$, and the selectivity correction terms by pooled 2SLS, using $z_{i t}, \overline{z_{i}}$, and calculated inverse Mills ratios as instruments. ${ }^{12}$ The estimation method advocated for this

\footnotetext{
${ }^{12}$ This corresponds to step (ii) in Semykina and Wooldridge’s Procedure 5.1. In the case of tobit selection, the selectivity correction terms are tobit residuals, which are not exogenous in the wage equation. Since the (calculated) inverse Mills ratios are (consistent estimates of) nonlinear functions of $Z_{i t}$ they are (asymptotically) exogenous and can be used as instruments. Since no consistent estimator is available for FE-probit specifications we calculate the inverse Mills ratios from a FE-logit model for participation.
} 
specification by Semykina and Wooldridge is pooled 2SLS. In order to allow for a more general error structure than required for the consistency of pooled 2SLS, we re-estimate the wage equation by RE-2SLS. Indeed, the wage equation (4) exhibits a composite disturbance term (with two "error components"), implying a nondiagonal variancecovariance matrix. Under the assumptions made this does not affect the consistency of pooled 2SLS, although a GLS method like RE-2SLS is in principle more efficient. In addition to pooled 2SLS and RE-2SLS, we also estimate a FE-2SLS wage equation including the time-varying regressors only, as a basis for comparison and for specification testing.

\section{The GSOEP panel data}

The empirical analysis is based on data of the German Socio-Economic Panel (GSOEP) for the years 1994-2005. ${ }^{13}$ The GSOEP is a representative survey of the German population, which includes detailed information on employment, demographic and personal characteristics. We select the female respondents aged between 16 and 45 at the time they entered the panel, who are not students or self-employed. This age interval represents the fertile period in a woman's life. The economic rationality for excluding self-employed and students is that both groups do not demand their reservation wage and that their choice of participation into the labour market is determined by other factors. ${ }^{14}$ Apart from economic considerations these restrictions keep our sample comparable with those used in other studies.

\footnotetext{
${ }^{13}$ In our analyses, we use the $95 \%$ version of GSOEP.

${ }^{14}$ Self-employed can establish their own wages, whereas students will settle for less than their reservation wage since their main objective is to build up their human capital.
} 
This section describes first the variables selected for the main wage equation and next the (exogenous) variables influencing the choice of working hours. Summary statistics of the main variables are presented in Table 1 . The dependent variable of primary interest is the logarithm of the hourly wage rate. Hourly wages are calculated by dividing current gross earnings by the number of contractual working hours. We use contractual rather than actual working hours here because the available wage data is monthly whereas actual working hours are weekly (and for a single week). Contractual working hours is therefore likely to be a better measure of monthly working time. ${ }^{15} \mathrm{We}$ exclude observations of hourly gross earnings lower than 3 euros and higher than 100 euros. Although Germany formally does not have a minimum wage, standards are introduced by employers and unions which provide a guideline for labour market negotiations. Therefore we reason that wages below the threshold of 3 euros are most likely due to measurement errors. ${ }^{16}$ We obtain a final sample of 9,967 women, 7,419 of whom earn wages at some time (resulting in 59,406 panel observations overall).

Our prime interest is to investigate how career breaks around maternity affect wages. In each wave of the panel, we measure the incidence of maternal leave as the share of time spent in maternal leave in each of the five preceding years (denoted $t-1, t-2$, $t-3, t-4, t-5) .{ }^{17}$ We interpret the time share of maternal leave in the previous calendar year $(t-1)$ as a short-run measure and the shares in previous years $(t-2, t-3, t-4, t-5)$ as controls

\footnotetext{
${ }^{15}$ Using actual working hours in a week to construct hourly wages from monthly earnings is likely to induce a common measurement error and hence spurious negative correlation between the working hours and the calculated hourly wage rate. We partly avoid the problem by using contractual hours of work. Contractual hours also contain measurement errors but these affect only the hourly wage calculation and do not contaminate the actual hours of work variable which is included as a regressor in the wage equation.

${ }^{16}$ See WSI-Tarifarchiv of the Hans Böckler Stiftung.

${ }^{17}$ This information is taken from the ARTKALEN file which indicates the activity status in the previous calendar year. Maternal leave covers the periods of maternity protection and maternity benefits as well as parental leave.
} 
for delayed effects. We take into account the past frequency of interruptions due to motherhood by including the number of children in the wage equation. Since other types of career interruptions may also affect the wage, we construct a dummy variable controlling for these in each of the last five years. The dummy variable combines the following types of interruptions: non-working, civil (or military) service, unemployment, and non working due to training or education.

The human capital development indicators appearing in the wage equation are education, training, mismatch between education and the present job, experience and firm tenure. Education is measured in institutionalised years of schooling. Our training variable gives information on training incidence relevant for work in the year previous to the survey and is coded 1 if respondents trained and 0 if they did not train. The mismatch variable is based on the question whether respondents work in a job corresponding to their education. The variable is coded 1 if respondents declared that their job did not match their education. Further, we distinguish between full-time work experience, parttime work experience, and accumulated unemployment spells; for full-time work experience an additional quadratic term is included. The tenure variable may account for firm-specific human capital and is expressed as firm tenure in years. ${ }^{18}$

The wage equation further includes the following explanatory variables: actual working hours, dummies for temporary work contract and firm size, dummy variables indicating if the individual lives in former East Germany and if her country of origin is non-Western, and year dummies. The "Mundlak terms" $\left(\overline{z_{i}}\right)$ included are either time

${ }^{18}$ The experience and tenure variables are based on the "generated files" of GSOEP which provide information on yearly labour market states. The mismatch variable was taken as such from the GSOEP generated files. It measures the preception of respondents concerning the match between their job and education. 
averages or initial levels of the explanatory variables of the participation equation, to be specified shortly.

(Insert TABLE 1 about here)

In the working hours (censored tobit) equation, we use actual hours worked as the limited dependent variable, with zero working hours standing for unemployment or inactivity. The need for child care time is reflected not only by the number of children, but in addition by a set of dummy variables indicating the age of a mother's youngest child in nine categories (age $<1,1$ through 5, 6-12, 13-18, and older; the reference category being women without children). "Other household income" means household income excluding the panel member's own wages. This consists of the earnings of other household members as well as asset income. It is calculated as the difference between the net monthly total household income and the current net monthly earnings of the respondent woman, and expressed in logarithms.

Further explanatory variables in the working hours equation are age and age squared, education (institutionalised years), and dummy variables indicating marital status ( 1 if married), bad health (the respondent declaring her health to be either "not so good" or "bad"), house ownership, whether an individual lives in former East Germany, and whether her country of origin is non-Western.

Time-constant Mundlak terms for both equations $\left(\overline{z_{i}}\right)$ are specified as either time averages or initial levels of time-varying variables that are assumed exogenous and observable for all panel members (participants and non-participants): average number of 
children, average education level, average logarithm of other household income, initial experience levels (full-time, part-time and unemployment), average tenure, the averages of the dummy variables reflecting the childcare need and bad health, and initial house ownership.

\section{Estimation results}

The first step in the estimation procedure is to estimate the working hours equation as a sequence of standard cross-sectional censored tobit regressions. Although we used such unrestricted year-by-year estimates to calculate the selectivity correction terms for use in the wage equation, we found that the year-by-year estimates do not differ much. To save space and improve readability, Table 2 reports a single set of coefficient estimates for the censored tobit working hours equation, pooled over the whole observation period 19942005. The coefficients of the Mundlak terms are omitted from the table.

(Insert TABLE 2 about here)

Inspection of the signs of the estimated coefficients reveals that all variables have effects in the expected direction. Having more children decreases the labour market participation of women, and mothers of young children work considerably shorter hours. This is especially true when the youngest child is younger than 6 years. Mothers hardly participate on the labour market when the youngest child is younger than one year. The results reflect the fact that the need for constant child care decreases as the child grows up and that mothers get more spare time when children go to school. When the youngest 
child in the household grows older, females do again increase their labour force participation. A striking result is that mothers with children older than 12 actually work more hours than women without children. Mothers with children who are 19 years or older work in general seven hours more than females without children (the reference group). Among the other variables, we find that an extra year of education and house ownership are associated with higher working hours, while other household income diminishes the need for paid work. Women living in former East Germany work slightly more hours than those in former West Germany which can be explained by the better availability of child care in this part of the country (see Kreyenfeld 2001).

The residuals from the year-by-year tobit estimates are retrieved to serve as selection correction terms in the wage equation, to which we now turn. Three models allowing for different degrees of heterogeneity are estimated: Pooled OLS and RE, both including Mundlak terms, and FE (in which Mundlak terms are redundant). All specifications include the selectivity correction terms (residuals from the tobit selection equation). The Mundlak terms are time-averages or initial levels of the exogenous variables as specified at the end of previous section. Table 3 presents results treating all regressors as exogenous.

(Insert TABLE 3 about here)

The fraction of the previous calendar year spent on maternal leave has a significant negative effect on the hourly wage in the present year. Since this coefficient measures the direct effect of maternal leave on wages in the first following year, we 
interpret it as the short term maternal leave penalty. This penalty is robustly negative under the different estimation methods. However, the size of the wage penalty varies between $10.3 \%$ in the pooled estimation and approximately $6 \%$ in the RE and $\mathrm{FE}$ estimation. The coefficients of the fractions spent on maternal leave in the calendar years t-2 until t-5 are smaller than the coefficient of the fraction spent on maternal leave in the previous year. This indicates that mothers' wages catch up over time. At the same time, the persistent negative coefficient of about $4.5 \%$ for the time spent on maternal leave in year t -4 implies that mothers are still confronted with a substantial wage penalty four years after they took the maternal leave. It is surprising, especially in the light of a human capital interpretation, to find a higher penalty four years after a maternal leave than two or three. However, a possible explanation for this resurgence in the fourth year is that some mothers, by returning to work only after taking the maximum length of parental leave, signal a relatively low degree of labour market attachment and are punished for this by a higher penalty compared to earlier returners.

Focusing on the effects of other work interruptions, we find that the occurrence of non-maternal interruptions in the preceding year also leads to substantial wage losses, although these losses are less than many estimates reported for Germany in the literature. The wage penalty of a work interruption other than maternal leave in the preceding year varies between $5.5 \%$ in the pooled estimation to $6.2 \%$ in the FE estimation. Non-maternal work interruptions in the years $\mathrm{t}-2$ and $\mathrm{t}-3$, in contrast with maternal interruptions at those lags, also have robust negative coefficients; but non-maternal work interruptions significantly affect wages only for three years. This means that maternal leave sometimes 
has a more persistent effect than other interruptions, and suggests that other factors than human capital depreciation are also influencing the wage penalty.

Considering the other explanatory variables, we find as would be expected that years of education, training, full-time and part-time work experience, firm tenure and firm size tend to have a positive effect on the wage rate; while unemployment experience, a temporary contract, and a mismatch between a woman's job and her education level have a negative effect on her wage. Moreover, women with a non-Western country of origin or living in former East Germany earn lower wages. It seems safe to say that the number of children has no direct effect in the wage equation, in addition to its indirect effect through actual working hours. The use of different estimation methods also influences the magnitude and sometimes the sign of these coefficients. The largest differences are between the FE and the pooled OLS estimates, with RE appearing as a compromise. The effects of full-time working experience, training, mismatch between education and job, firm tenure, the firm size and the number of children on the wage become smaller (or even insignificantly negative) in the FE estimations. Clearly, the estimation of the fixed effects interferes with the estimation of other effects that only slowly evolve over time (part-time work experience, training, firm tenure). On the other hand, the negative effect of unemployment experience increases strikingly (though its standard error increases proportionately). The sign of the coefficient of the working hours variable becomes negative in the FE estimation. The selectivity correction terms are small and statistically insignificant in the pooled estimation, but become very significant in the RE and FE models, even though they remain rather small in magnitude. 
Another feature which emerges from our wage equations in Table 3 deserves attention. The pooled OLS regression suffers from positive residual autocorrelation. Although a formal test is complicated, there remain practically no signs of incomplete dynamics once individual unobserved heterogeneity is accounted for (either in the FE or in the RE form). To a large extent dynamics and heterogeneity seem to capture each other's effects. Whereas the RE specification is successful in terms of capturing heterogeneity, it is rejected by a Hausman test against the FE specification. We attribute the rejection to the specific distributional assumptions made which does not necessarily affect the coefficient estimates very much and clearly does not impair the goodness of fit at all. In our experience this is the usual outcome with large data sets and the price to be paid for the theoretical gain in efficiency.

(Insert TABLE 4 about here)

Finally, in Table 4, we allow for endogeneity of the working hours variable as well as the selection correction terms (tobit residuals). The number of hours worked by women is allowed to be endogenous with respect to the wage rate since it is determined as an outcome of the labour supply decision, and clearly high earning women might work more hours and interrupt their careers less frequently than women who earn a lower wage. The actual working hours variable is instrumented with age and age squared, other monthly household income (in logarithm), house ownership, number of children, the need for child care, marital status and bad health. These are variables that are not under the control of an individual, at least in the short run, and that can be assumed independent of 
the error components in equations (4) and (5). Since they appear in the working hours equation they are relevant instruments. It might be argued that in a life cycle context the number of children, as well as variables measuring education and experience, should be treated as endogenous. Unfortunately, the time span of personal histories in our data is too limited for such purposes. The equations include the same selectivity regressors and the same Mundlak time-averages or initial levels of the exogenous variables as in Table 3. As instrumental variables targeting the selectivity regressors (tobit residuals) we used inverse Mills ratios calculated from a FE logit participation equation. ${ }^{19}$

The first column presents the 2SLS pooled estimates, the second column the RE2SLS estimates, and the third column the FE-2SLS estimates. Allowing for the endogeneity of actual working hours leads to some substantial differences in results. The working hours coefficient itself turns negative and quite significant. According to these estimates, adding another day (8 hours) to one's working week would cost around $10 \%$ of the wage rate. Our interpretation is that 2SLS corrects a positive simultaneity bias in the working hours coefficients of Table 3 and identifies a negatively sloped labour demand function reflecting the decreasing marginal productivity associated with increasing actual (though not necessarily contractual) working hours. It is furthermore possible that we are at the same time redressing measurement error and/or omitted variable biases. Consider in particular the case that actual working hours are positively correlated with job level or status and are capturing their effects. The consequence would be a positive omitted

\footnotetext{
${ }^{19}$ See Footnote 12. The justification for using a FE logit rather than FE probit selection equation for the calculation of the inverse Mills ratios is that the incidental parameters can be eliminated in the former and not in the latter. A separate instrumental variable containing the inverse Mills ratio is constructed for each of the 12 panel years.
} 
variable bias in the working hours coefficient consistent with the estimates we see in Table 3.

The working hours coefficient is not the only one affected by the 2SLS method. The cost of a maternal leave in terms of the mother's wage in the first year following the interruption increases to $19 \%$ in the pooled estimation, $14 \%$ in the RE estimation and $10 \%$ in the FE model. Penalties for other career interruptions do not increase or only slightly. The number of children still has no additional direct effect in the wage equation. Most experience effects are enhanced but again the estimation of fixed effects can interfere with them.

To sum up we have found, using different methods, a wage penalty for maternal leave ranging between 6 and almost 20\%; but the estimates with the best theoretical properties range only from 10 to $14 \%$. The selectivity correction terms are statistically significant, although less so in the pooled estimations than in the RE and FE models. The selectivity correction has a limited impact on the coefficient estimates in the pooled and RE models; it causes more changes in the FE model. ${ }^{20}$ Accounting for heterogeneity by fixed and random effects reduces the estimated penalties by one third to one half. Accounting for the endogeneity of working hours on the contrary practically doubles the penalty estimates. Even more noteworthy is the effect of instrumenting actual working hours on the working hours coefficient itself. From close to zero in Table 3, this coefficient turns strongly negative in the two-stage least squares estimates of Table 4 . This is consistent with the idea that we identify a labour demand relationship negatively

\footnotetext{
${ }^{20}$ Estimates excluding the selectivity correction but taking the endogeneity of working hours into account are available in Table 5 in the Annex.
} 
sloped because of decreasing marginal productivity. It is suggested that there is a positive premium on part-time work causing bias in OLS estimates of the wage penalty.

How do our results compare to the estimates based on German data cited earlier? The estimated penalties of Beblo and Wolf (2002), Kunze (2002), Kunze and Ejrnaes (2004) and Beblo and Wolf (2006) range approximately from 10\% to 30\% (although insignificant in the case of Beblo and Wolf 2002). Our estimate best comparable in terms of methodological choices is the FE estimate in Table 3, which is only 6\%. Apart from methodological choices, this large discrepancy in the magnitude of the penalty may also be explained by differences in data sources and sample definitions, such as a longer time span and the restriction to full-time workers. For instance, Kunze and Ejrnaes (2004) focus on women who work full-time, have a strong labour market attachment, and return to work within one year after a first birth. In Beblo and Wolf (2006) women working in large firms are over-represented as it is easier to find a match for them.

Regarding the persistence of maternal leave effects in time, we see again a relatively optimistic pattern emerge from our estimates. Kunze (2002) finds delayed effects that decrease only very slowly over the years. In the fifth year following a career interruption (maternal or otherwise) we find no remaining wage penalty. At first sight our estimates may seem roughly consistent with the hypothesis of a human capital depreciation following career interruptions and a period of restoration upon return to the labour market. Nonetheless our results indicate that this explanation is incomplete; they suggest the existence of additional signalling effects linked to the length of maternal leave taken. In particular the choice of some mothers to take the maximum duration of 
leave might be taken as a negative signal on the labour market. We think this point deserves further investigation.

\section{Concluding remarks}

In this paper, we analyzed the wage penalty effect of maternal leave using data on women in their fertile age from GSOEP. We adopted the estimation framework proposed by Wooldridge (1995) and Semykina and Wooldridge (2006), but replaced their probit selection equation by a tobit specification. This extension allowed us to exploit the available working hours information.

We have focused in particular on estimating the short term and delayed wage penalties of the fraction of time in a year spent on maternal leave. When accounting for unobserved heterogeneity and selectivity we found a sizeable wage penalty in the first year following the maternal leave of about $6 \%$. When accounting in addition for the endogeneity of working hours we found a penalty of 10 to $14 \%$. The occurrence of other types of interruptions in the previous year tends to result in a somewhat lower wage penalty. The rough similarity in these figures suggests that both may be interpreted as the result of a comparable depreciation of human capital in the short run. Delayed effects, however, reveal different patterns. The wage penalty is very small or inexistent for maternal leave taken two or three years ago, suggesting that mothers catch up quickly over time; whereas the effect of non-maternal leaves decreases more gradually. However, mothers seem to undergo a resurgence in wage penalty four years after the start of a maternal leave. No such resurgence is observed with other types of interruptions. An intriguing interpretation is that this peculiarity reflects a signalling effect affecting 
mothers who return to work only after having taken up the maximum legal length of parental leave to the end. The differences in delayed effects between maternal leaves and other types of interruptions are not predicted by human capital theory and indicate the need for additional explanations, probably of the signalling type.

On a methodological note, we conclude that allowing for endogeneity of labour supply in the wage equation, in addition to correcting for unobserved heterogeneity and sample selectivity, has a large impact on the estimates. Our wage equation turned out to be quite sensitive in this respect. Treating working hours as endogenous more or less doubled the initial size of the maternal leave wage penalty, resulting in our reported range of $10-14 \%$. Instrumenting working hours also drastically changed the working hours coefficient itself, resulting in a negatively sloped relationship as would be expected in a labour demand function.

Compared to other studies on the effects of maternity and child care interruptions on the wages of mothers in Germany, our estimates are rather optimistic in terms of both the magnitude and the persistence of the penalty for maternal leave. 


\section{References}

Albrecht, J. W., Edin, P.-A., Sundström, M., Vroman S.B. (1999), Career Interruptions and Subsequent Earnings: A Reexamination Using Swedish Data, The Journal of Human Resources, 34(2), 294-311.

Amuedo-Dorantes, C., Kimmel, J. (2005), The Motherhood Wage Gap for Women in the United States: The Importance of College and Fertility Delay, Review of Economics of Household, 3(1), 17-48(32).

Anderson, D., Binder, M., Krause, K. (2002), The Motherhood Wage Penalty: Which Mothers Pay it and Why?, The American Economic Review, 92(2), 354-358.

Beblo, M., Bender, S., Wolf, E. (2006), The Wage Effects of Entering Motherhood: A Within-firm Matching Approach, IAB Discussion Paper, 13, 1-40.

Beblo, M., Wolf, E. (2002), Wage Penalties for Career Interruptions: An Empirical Analysis for West Germany, ZEW Working Paper, 02-45.

Bender, S., Kohlman, A., Lang S. (2003), Women Work and Motherhood: Changing Employment penalties for Motherhood in West Germany after 1945- A comparative Analysis of cohorts born 1934-1971, Max Planck Institute for Demographic Research Working Paper, 2003-006, 1-29.

Budig, M.J., England P. (2001), The Wage Penalty for Motherhood, American Sociological Review, 66(2), 204-225.

Chamberlain, G., (1980), Analysis of Covariance with Qualitative Data, Review of Economic Studies, XLVII, 225-238.

Datta Gupta, N., Smith, N. (2002), Children and Career Interruptions: The Family Gap in Denmark, Economica, 59(2), 243-266.

Davies, R., Pierre, G. (2005), The Family Gap in Pay in Europe: A Cross-Country Study, Labour Economics, 12, 469-486.

Dustmann C., Rochina-Barrachina, M.E. (2007), Selection Correction in Panel Data Models: An Application to Labour Supply and Wages, Econometrics Journal, 10, 263293.

Dustmann, C., van Soest, A. (1998), Public and Private Sector Wages of Male Workers in Germany, European Economic Review, 42, 1417-1441.

Harkness, S., Waldfogel, J., (2003). “The Family Gap in Pay: Evidence from Seven Industrialized Countries.” Research in Labor Economics, 22, 369-414. 
Heckman, J.J. (1976), The Common Structure of Statistical Models of Truncation, Sample Selection and Limited Dependent Variables and a Simple Estimator for such models, Annals of Economic and Social Measurement, 5/4, 475-492.

Heckman, J.J. (1979), Sample Selection Bias as a Specification Error, Econometrica, 47, 153-161.

Kreyenfeld, M. (2001), Employment and fertility in East Germany in the 1990s, Dissertation, Max-Planck Institute for Demographic Research, Rostock, 1-255.

Kunze, A. (2002), The Timing of Careers and Human Capital Depreciation, IZA Discussion Paper, 509, 1-24.

Kunze, A., Ejrnaes, M. (2004), Wage Dips and Drops around First Birth, IZA Discussion Paper, 1011, 1-56.

Kyriazidou, E. (1997), Estimation of a Panel Data Sample Selection Model, Econometrica, 65, 1335-1364.

Lundberg, S., Rose, E. (2000), Parenthood and the Earnings of Married Men and Women, Labour Economics, 7, 689-710.

Mincer, J., Ofek, H. (1982), Interrupted Work Careers: Depreciation and Restoration of Human Capital, Journal of Human Resources, 17(1), 3-24.

Mincer, J., Polachek, S. (1974), Family Investments in Human Capital: Earnings of Women, Journal of Political Economy, 82 (2), Part 2, s76- s108.

Mundlak, Y. (1978), On the Pooling of Time Series and Cross-Section Data, Econometrica, 46, 69-85.

Olivetti, C., Petrongolo, B. (2006), Unequal Pay or Unequal Employment?: A CrossCountry Analysis of Gender Gaps, IZA Discussion Paper, 1941, 1-46

Rochina-Barrachina, M.E. (1999), A New Estimator for Panel Data Sample Selection Models, Annales d'Economie et de Statistique, 55/56, 153-181.

Semykina, A., Wooldridge, J. (2006), Estimating Panel data models in presence of endogeneity and selection: theory and application, Working paper, 1-35.

Simonsen, M., Skipper, L. (2006), The Costs of Motherhood: An Analysis using Matching Estimators, Journal of Applied Econometrics, 21, 919-934.

Spiess, K. C., Wrohlich, K. (2006), The parental leave benefit reform in Germany: Costs and Labour Market outcomes of moving towards a Scandinavian model, IZA Discussion Paper, 2372, 1-22. 
Waldfogel, J. (1998), The Family Gap for Young Women in the United States and Britain: Can Maternity Leave Make a Difference?, Journal of Labor Economics, 16(3), 505-545.

Wooldridge, J. (1995), Selection corrections for panel data models under conditional mean independence assumptions, Journal of Econometrics, 68, 115-132.

Wooldridge, J. (2002), Econometric Analysis of Cross Section and Panel Data, MIT Press. 
Table 1 Summary statistics

\begin{tabular}{|c|c|c|c|}
\hline Variable description & Entire sample & Participant & Non-participant \\
\hline $\begin{array}{l}\text { Participation } \\
\text { ( } 1 \text { if working) }\end{array}$ & 0.61 & 1 & 0 \\
\hline $\begin{array}{l}\text { Actual working hours } \\
\text { in the previous week }\end{array}$ & & $\begin{array}{c}33.86 \\
(11.95)\end{array}$ & $\begin{array}{c}0.00 \\
(0.00)\end{array}$ \\
\hline $\begin{array}{l}\text { Hourly earnings } \\
\text { (in logarithms) }\end{array}$ & & $\begin{array}{l}2.36 \\
(0.46)\end{array}$ & \\
\hline $\begin{array}{l}\text { Fraction of previous year in maternal } \\
\text { leave }\end{array}$ & $\begin{array}{c}0.08 \\
(0.25)\end{array}$ & $\begin{array}{l}0.03 \\
(0.14)\end{array}$ & $\begin{array}{l}0.17 \\
(0.35)\end{array}$ \\
\hline $\begin{array}{l}\text { Fraction of year } \mathrm{t}-2 \text { spent in maternal } \\
\text { leave }\end{array}$ & $\begin{array}{c}0.08 \\
(0.25)\end{array}$ & $\begin{array}{c}0.04 \\
(0.18)\end{array}$ & $\begin{array}{l}0.15 \\
(0.32)\end{array}$ \\
\hline $\begin{array}{l}\text { Fraction of year } \mathrm{t}-3 \text { spent in maternal } \\
\text { leave }\end{array}$ & $\begin{array}{l}0.08 \\
(0.25)\end{array}$ & $\begin{array}{c}0.05 \\
(0.20)\end{array}$ & $\begin{array}{c}0.14 \\
(0.31)\end{array}$ \\
\hline $\begin{array}{l}\text { Fraction of year t- } 4 \text { spent in maternal } \\
\text { leave }\end{array}$ & $\begin{array}{c}0.08 \\
(0.25)\end{array}$ & $\begin{array}{l}0.06 \\
(0.22)\end{array}$ & $\begin{array}{l}0.13 \\
(0.31)\end{array}$ \\
\hline $\begin{array}{l}\text { Fraction of year t- } 5 \text { spent in maternal } \\
\text { leave }\end{array}$ & $\begin{array}{l}0.08 \\
(0.25)\end{array}$ & $\begin{array}{l}0.06 \\
(0.22)\end{array}$ & $\begin{array}{c}0.12 \\
(0.30)\end{array}$ \\
\hline $\begin{array}{l}\text { Other interruptions in previous year } \\
\text { (1 if interruption) }\end{array}$ & $\begin{array}{c}0.31 \\
(0.46)\end{array}$ & $\begin{array}{c}0.10 \\
(0.30)\end{array}$ & $\begin{array}{l}0.67 \\
(0.47)\end{array}$ \\
\hline Number of children & $\begin{array}{c}1.26 \\
(1.21)\end{array}$ & $\begin{array}{c}1.12 \\
(1.10)\end{array}$ & $\begin{array}{l}1.48 \\
(1.31)\end{array}$ \\
\hline Age of youngest child in years & $\begin{array}{l}9.58 \\
(7.33)\end{array}$ & $\begin{array}{l}11.61 \\
(6.86)\end{array}$ & $\begin{array}{l}6.80 \\
(7.08)\end{array}$ \\
\hline Age in years & $\begin{array}{l}33.98 \\
(9.46)\end{array}$ & $\begin{array}{l}35.28 \\
(9.00)\end{array}$ & $\begin{array}{l}31.97 \\
(9.83)\end{array}$ \\
\hline $\begin{array}{l}\text { Bad health } \\
\text { (1 if health "not so good" or "bad") }\end{array}$ & $\begin{array}{c}0.10 \\
(0.30)\end{array}$ & $\begin{array}{c}0.09 \\
(0.29)\end{array}$ & $\begin{array}{l}0.13 \\
(0.34)\end{array}$ \\
\hline $\begin{array}{l}\text { Marital status } \\
\quad \text { ( } 1 \text { if married })\end{array}$ & $\begin{array}{l}0.58 \\
(0.49)\end{array}$ & $\begin{array}{l}0.56 \\
(0.49)\end{array}$ & $\begin{array}{l}0.61 \\
(0.48)\end{array}$ \\
\hline Education in institutionalised years & $\begin{array}{l}11.78 \\
(2.47)\end{array}$ & $\begin{array}{l}12.11 \\
(2.46)\end{array}$ & $\begin{array}{l}11.21 \\
(2.37)\end{array}$ \\
\hline $\begin{array}{l}\text { Training } \\
\qquad \text { (1 if trained) }\end{array}$ & $\begin{array}{l}0.06 \\
(0.24)\end{array}$ & $\begin{array}{l}0.10 \\
(0.31)\end{array}$ & $\begin{array}{l}0.00 \\
(0.00)\end{array}$ \\
\hline Full-time work experience in years & $\begin{array}{l}7.49 \\
(7.41)\end{array}$ & $\begin{array}{l}9.06 \\
(7.80)\end{array}$ & $\begin{array}{c}4.98 \\
(5.95)\end{array}$ \\
\hline Part-time work experience in years & $\begin{array}{l}2.29 \\
(4.09)\end{array}$ & $\begin{array}{c}2.95 \\
(4.61)\end{array}$ & $\begin{array}{l}1.21 \\
(2.77)\end{array}$ \\
\hline Unemployment experience in years & $\begin{array}{c}0.62 \\
(1.46)\end{array}$ & $\begin{array}{c}0.46 \\
(1.09)\end{array}$ & $\begin{array}{l}0.90 \\
(1.90)\end{array}$ \\
\hline $\begin{array}{l}\text { Temporary contract } \\
\text { ( } 1 \text { if temporary contract) }\end{array}$ & & $\begin{array}{l}0.16 \\
(0.36)\end{array}$ & \\
\hline $\begin{array}{l}\text { Mismatch } \\
\quad(1 \text { if mismatch })\end{array}$ & & $\begin{array}{c}0.45 \\
(0.50)\end{array}$ & \\
\hline Firm tenure in years & & $\begin{array}{c}6.93 \\
(7.05)\end{array}$ & \\
\hline $\begin{array}{l}\text { Firm size } \\
\qquad(1 \text { if } 200 \text { workers or more) }\end{array}$ & & $\begin{array}{l}0.39 \\
(0.49)\end{array}$ & \\
\hline East (1 if living in Eastern Germany) & $\begin{array}{c}0.23 \\
(0.42)\end{array}$ & $\begin{array}{l}0.26 \\
(0.44)\end{array}$ & $\begin{array}{c}0.23 \\
(0.42)\end{array}$ \\
\hline $\begin{array}{l}\text { Other household income, monthly } \\
\text { (in logarithm) }\end{array}$ & $\begin{array}{l}7.37 \\
(0.80)\end{array}$ & $\begin{array}{c}7.21 \\
(0.91)\end{array}$ & $\begin{array}{l}7.61 \\
(0.52)\end{array}$ \\
\hline $\begin{array}{l}\text { House ownership } \\
\quad \text { ( } 1 \text { if household own their house) }\end{array}$ & $\begin{array}{c}0.42 \\
(0.49)\end{array}$ & $\begin{array}{c}0.43 \\
(0.50)\end{array}$ & $\begin{array}{l}0.41 \\
(0.49)\end{array}$ \\
\hline Number of observations & 59,406 & 33,791 & 21,352 \\
\hline Number of individuals ${ }^{\mathrm{R}}$ & 9,967 & 7,419 & 6,304 \\
\hline
\end{tabular}

Notes: Main entries are sample means, numbers in parentheses are sample standard deviations.

${ }^{\mathrm{R}}$ We observe 3,756 individuals who appear both as a participant and as a non-participant in different waves of the panel. 
Table 2 Selection equation

\begin{tabular}{|c|c|}
\hline Dependent variable: Participation & $\begin{array}{l}\text { Tobit } \\
\text { model }\end{array}$ \\
\hline Number of children & $\begin{array}{l}-2.675 \\
(.1497)\end{array}$ \\
\hline Youngest child aged $<1$ & $\begin{array}{l}-40.518 \\
(0.738)\end{array}$ \\
\hline Youngest child aged 1 & $\begin{array}{l}-29.357 \\
(0.639)\end{array}$ \\
\hline Youngest child aged 2 & $\begin{array}{l}-21.355 \\
(0.638)\end{array}$ \\
\hline Youngest child aged 3 & $\begin{array}{l}-13.697 \\
(0.648)\end{array}$ \\
\hline Youngest child aged 4 & $\begin{array}{l}-10.531 \\
(0.662)\end{array}$ \\
\hline Youngest child aged 5 & $\begin{array}{l}-8.786 \\
(0.673)\end{array}$ \\
\hline Youngest child aged between 6 and 12 & $\begin{array}{l}-1.559 \\
(0.420)\end{array}$ \\
\hline Youngest child aged between 13 and 18 & $\begin{array}{c}4.857 \\
(0.452)\end{array}$ \\
\hline Youngest child aged $>18$ & $\begin{array}{c}7.592 \\
(0.548)\end{array}$ \\
\hline $\begin{array}{l}\text { Marital status } \\
\qquad(1 \text { if married })\end{array}$ & $\begin{array}{l}-0.731 \\
(0.291)\end{array}$ \\
\hline Education in institutionalised years & $\begin{array}{c}2.811 \\
(0.150)\end{array}$ \\
\hline $\begin{array}{l}\text { Bad health } \\
\qquad \text { (1 if health "not so good" or "bad") }\end{array}$ & $\begin{array}{l}-0.375 \\
(0.451)\end{array}$ \\
\hline Age in years & $\begin{array}{c}1.597 \\
(0.108)\end{array}$ \\
\hline Age squared & $\begin{array}{l}-0.031 \\
(.002)\end{array}$ \\
\hline $\begin{array}{l}\text { Other household income, monthly } \\
\text { (in logarithm) }\end{array}$ & $\begin{array}{l}-6.757 \\
(0.211)\end{array}$ \\
\hline $\begin{array}{l}\text { House ownership } \\
\qquad \text { (1 if house owner) }\end{array}$ & $\begin{array}{c}4.380 \\
(0.326)\end{array}$ \\
\hline $\begin{array}{l}\text { East } \\
\\
\text { (1 if living in Eastern Germany) }\end{array}$ & $\begin{array}{c}1.859 \\
(0.267)\end{array}$ \\
\hline $\begin{array}{l}\text { Country of origin } \\
\qquad(1 \text { if non-Western) }\end{array}$ & $\begin{array}{l}-1.462 \\
(0.348)\end{array}$ \\
\hline Mundlak terms & Included \\
\hline Number of effective observations & 47,321 \\
\hline Number of individuals & 8,355 \\
\hline
\end{tabular}

Notes: Standard errors (in parentheses) should be interpreted as asymptotic lower bounds. Year dummies and Mundlak terms are included. For convenience, the tobit coefficients shown are pooled estimates over 1994-2005. Year-by-year estimates (which exhibit little variation over time) have been used for the calculation of the selectivity correction terms included in the wage equation. 
Table 3 Wage equation with selectivity correction: Pooled, RE and FE

\begin{tabular}{|c|c|c|c|}
\hline "Dependent variable: Log hourly wage & Pooled & RE model & FE model \\
\hline Actual working hours & 0.051 & 0.005 & -0.050 \\
\hline (hours divided by 40) & $(0.026)$ & $(0.022)$ & $(0.026)$ \\
\hline \multirow[t]{2}{*}{ Fraction of previous year in maternal leave } & -0.103 & -0.063 & -0.061 \\
\hline & $(0.032)$ & $(0.023)$ & $(0.024)$ \\
\hline \multirow{2}{*}{ Fraction of year t-2 spent in maternal leave } & -0.006 & -0.011 & -0.010 \\
\hline & $(0.029)$ & $(0.019)$ & $(0.020)$ \\
\hline \multirow[t]{2}{*}{ Fraction of year t-3 spent in maternal leave } & 0.011 & 0.011 & 0.002 \\
\hline & $(0.026)$ & $(0.018)$ & $(0.018)$ \\
\hline \multirow[t]{2}{*}{ Fraction of year $\mathrm{t}-4$ spent in maternal leave } & -0.044 & -0.048 & -0.045 \\
\hline & $(0.024)$ & $(0.016)$ & $(0.017)$ \\
\hline \multirow{2}{*}{ Fraction of year t- 5 spent in maternal leave } & -0.012 & -0.006 & -0.008 \\
\hline & $(0.021)$ & $(0.015)$ & $(0.016)$ \\
\hline \multirow{2}{*}{ Dummy if other interruptions in year $\mathrm{t}-1$} & -0.055 & -0.059 & -0.062 \\
\hline & $(0.016)$ & $(0.012)$ & $(0.013)$ \\
\hline \multirow{2}{*}{ Dummy if other interruptions in year $\mathrm{t}-2$} & -0.031 & -0.041 & -0.041 \\
\hline & $(0.014)$ & $(0.010)$ & $(0.011)$ \\
\hline \multirow[t]{2}{*}{ Dummy if other interruptions in year $\mathrm{t}-3$} & -0.044 & -0.048 & -0.044 \\
\hline & $(0.014)$ & $(0.009)$ & $(0.010)$ \\
\hline \multirow{2}{*}{ Dummy if other interruptions in year $t-4$} & -0.013 & -0.002 & 0.007 \\
\hline & $(0.013)$ & $(0.009)$ & $(0.010)$ \\
\hline \multirow{2}{*}{ Dummy if other interruptions in year $\mathrm{t}-5$} & -0.021 & -0.019 & -0.015 \\
\hline & $(0.012)$ & $(0.009)$ & $(0.009)$ \\
\hline \multirow{2}{*}{ Number of children } & 0.053 & 0.026 & 0.004 \\
\hline & $(0.021)$ & $(0.016)$ & $(0.017)$ \\
\hline \multirow[t]{2}{*}{ Education in institutionalised years } & 0.012 & 0.016 & 0.017 \\
\hline & $(0.005)$ & $(0.005)$ & $(0.005)$ \\
\hline \multirow{2}{*}{$\begin{array}{l}\text { Full-time work experience in years } \\
\text { (coefficient multiplied by 100) }\end{array}$} & 3.026 & 3.614 & 1.590 \\
\hline & $(0.239)$ & $(0.299)$ & $(1.080)$ \\
\hline \multirow{2}{*}{$\begin{array}{l}\text { Full-time work experience squared } \\
\text { (coefficient multiplied by } 10,000 \text { ) }\end{array}$} & -1.758 & -3.213 & -3.894 \\
\hline & $(0.475)$ & $(0.651)$ & $(1.054)$ \\
\hline \multirow{2}{*}{$\begin{array}{l}\text { Part-time work experience in years } \\
\text { (coefficient multiplied by 100) }\end{array}$} & 1.268 & 0.997 & -0.750 \\
\hline & $(0.242)$ & $(0.287)$ & (1.047) \\
\hline \multirow{2}{*}{$\begin{array}{l}\text { Unemployment experience in years } \\
\text { (coefficient multiplied by 100) }\end{array}$} & -1.909 & -2.693 & -7.588 \\
\hline & $(0.522)$ & $(0.690)$ & $(1.843)$ \\
\hline \multirow{2}{*}{$\begin{array}{l}\text { Temporary contract } \\
\text { ( } 1 \text { if temporary contract) }\end{array}$} & -0.089 & -0.101 & -0.100 \\
\hline & $(0.013)$ & $(0.011)$ & $(0.013)$ \\
\hline \multirow{2}{*}{$\begin{array}{l}\text { Training } \\
\text { (1 if trained) }\end{array}$} & 0.043 & 0.003 & -0.008 \\
\hline & $(0.011)$ & $(0.008)$ & $(0.009)$ \\
\hline Mismatch & -0.134 & -0.117 & -0.096 \\
\hline (1 if mismatch) & $(0.007)$ & $(0.009)$ & $(0.011)$ \\
\hline Firm tenure in years & 0.432 & 0.165 & -0.117 \\
\hline (coefficient multiplied by 100) & $(0.069)$ & $(0.077)$ & $(0.096)$ \\
\hline Firm size & 0.167 & 0.107 & .048 \\
\hline ( 1 if 200 workers or more) & $(0.007)$ & $(0.810)$ & $(.011)$ \\
\hline East & -0.256 & -0.246 & -0.231 \\
\hline (1 if living in Eastern Germany) & $(0.008)$ & $(0.014)$ & $(0.052)$ \\
\hline Country of origin & -0.062 & -0.059 & \\
\hline (1 if non-Western) & $(0.012)$ & $(0.019)$ & \\
\hline Mundlak terms & Included & Included & Redundant \\
\hline Standard error individual effects & & 0.267 & 0.359 \\
\hline Standard error residual & 0.312 & 0.185 & 0.185 \\
\hline Autocorrelation of residuals & 0.694 & -0.043 & -0.071 \\
\hline & $(0.009)$ & $(0.013)$ & $(0.013)$ \\
\hline Hausman Test RE vs FE chi-square(35) & & & 228.50 \\
\hline p-value Hausman test & & & $(0.000)$ \\
\hline Number of effective observations & 9,137 & 9,137 & 9,137 \\
\hline Number of individuals & 2,901 & 2,901 & 2,901 \\
\hline
\end{tabular}

Notes: Standard errors (in parentheses) should be interpreted as asymptotic lower bounds. Year dummies and selection correction terms (tobit residuals) are included though not reported. Mundlak terms are included in the pooled and RE models but redundant in the FE model. The selection correction terms have significant effects in the RE and FE models but not in the Pooled estimates. 
Table 4: Wage equation with selectivity correction and endogeneity: Two stage least squares

\begin{tabular}{|c|c|c|c|}
\hline Dependent variable: Log hourly wage & Pooled & RE model & FE model \\
\hline Actual working hours & -0.495 & -0.612 & -0.494 \\
\hline (hours divided by 40) & $(0.095)$ & $(0.106)$ & $(0.189)$ \\
\hline \multirow[t]{2}{*}{ Fraction of previous year in maternal leave } & -0.193 & -0.139 & -0.101 \\
\hline & $(0.038)$ & $(0.029)$ & $(0.032)$ \\
\hline \multirow[t]{2}{*}{ Fraction of year $\mathrm{t}-2$ spent in maternal leave } & -0.025 & -0.033 & -0.016 \\
\hline & $(0.031)$ & $(0.022)$ & $(0.022)$ \\
\hline \multirow{2}{*}{ Fraction of year $\mathrm{t}-3$ spent in maternal leave } & 0.010 & 0.006 & 0.002 \\
\hline & $(0.028)$ & $(0.020)$ & $(0.020)$ \\
\hline \multirow[t]{2}{*}{ Fraction of year $\mathrm{t}-4$ spent in maternal leave } & -0.074 & -0.061 & -0.044 \\
\hline & $(0.026)$ & $(0.018)$ & $(0.018)$ \\
\hline \multirow{2}{*}{ Fraction of year $t-5$ spent in maternal leave } & -0.021 & -0.019 & -0.010 \\
\hline & $(0.023)$ & $(0.017)$ & $(0.017)$ \\
\hline \multirow[t]{2}{*}{ Dummy if other interruptions in year $\mathrm{t}-1$} & -0.095 & -0.086 & -0.072 \\
\hline & $(0.019)$ & $(0.014)$ & $(0.014)$ \\
\hline \multirow[t]{2}{*}{ Dummy if other interruptions in year $\mathrm{t}-2$} & -0.064 & -0.065 & -0.051 \\
\hline & $(0.016)$ & $(0.012)$ & $(0.012)$ \\
\hline \multirow{2}{*}{ Dummy if other interruptions in year $\mathrm{t}-3$} & -0.071 & -0.065 & -0.050 \\
\hline & $(0.016)$ & $(0.011)$ & $(0.011)$ \\
\hline \multirow[t]{2}{*}{ Dummy if other interruptions in year $t-4$} & -0.028 & -0.008 & 0.008 \\
\hline & $(0.015)$ & $(0.010)$ & $(0.011)$ \\
\hline \multirow{2}{*}{ Dummy if other interruptions in year $\mathrm{t}-5$} & -0.043 & -0.027 & -0.015 \\
\hline & $(0.014)$ & $(0.010)$ & $(0.010)$ \\
\hline \multirow[t]{2}{*}{ Number of children } & 0.025 & -0.017 & -0.022 \\
\hline & $(0.024)$ & $(0.019)$ & $(0.021)$ \\
\hline \multirow[t]{2}{*}{ Education in institutionalised years } & 0.015 & 0.016 & 0.016 \\
\hline & $(0.005)$ & $(0.005)$ & $(0.005)$ \\
\hline \multirow{2}{*}{$\begin{array}{l}\text { Full-time work experience in years } \\
\text { (coefficient multiplied by 100) }\end{array}$} & 4.031 & 4.872 & 4.108 \\
\hline & $(0.309)$ & $(0.396)$ & (1.550) \\
\hline \multirow{2}{*}{$\begin{array}{l}\text { Full-time work experience squared } \\
\text { (coefficient multiplied by } 10,000 \text { ) }\end{array}$} & -1.479 & -3.972 & -4.659 \\
\hline & $(0.516)$ & $(0.730)$ & $(1.180)$ \\
\hline \multirow{2}{*}{$\begin{array}{l}\text { Part-time work experience in years } \\
\text { (coefficient multiplied by 100) }\end{array}$} & -0.725 & 0.040 & 1.566 \\
\hline & $(0.415)$ & $(0.359)$ & $(1.469)$ \\
\hline \multirow{2}{*}{$\begin{array}{l}\text { Unemployment experience in years } \\
\text { (coefficient multiplied by 100) }\end{array}$} & -0.870 & -2.740 & -9.119 \\
\hline & $(0.588)$ & $(0.758)$ & (2.083) \\
\hline \multirow{2}{*}{$\begin{array}{l}\text { Temporary contract } \\
\text { ( } 1 \text { if temporary contract) }\end{array}$} & -0.048 & -0.060 & -0.081 \\
\hline & $(0.016)$ & $(0.014)$ & $(0.016)$ \\
\hline Training & 0.071 & 0.016 & -0.003 \\
\hline (1 if trained) & $(0.013)$ & $(0.009)$ & $(0.009)$ \\
\hline Mismatch & -0.155 & -0.132 & -0.100 \\
\hline (1 if mismatch) & $(0.009)$ & $(0.010)$ & $(0.012)$ \\
\hline Firm tenure in years & 0.396 & 0.208 & -0.010 \\
\hline (coefficient multiplied by 100 ) & $(0.075)$ & $(0.086)$ & $(0.102)$ \\
\hline Firm size & 0.186 & 0.124 & 0.052 \\
\hline ( 1 if 200 workers or more) & $(0.008)$ & $(0.009)$ & $(0.011)$ \\
\hline East & -0.207 & -0.166 & -0.238 \\
\hline (1 if living in Eastern Germany) & $(0.012)$ & $(0.020)$ & $(0.055)$ \\
\hline Country of origin & -0.044 & -0.037 & \\
\hline ( 1 if non-Western) & $(0.013)$ & $(0.021)$ & \\
\hline Mundlak terms & Included & Included & Redundant \\
\hline Standard error individual effects & & 0.275 & 0.410 \\
\hline Standard error residual & 0.337 & 0.196 & 0.195 \\
\hline Autocorrelation of residuals & 0.724 & -0.012 & -0.035 \\
\hline & $(0.009)$ & $(0.013)$ & $(0.013)$ \\
\hline Hausman Test RE vs FE chi-square(28) & & & 118.04 \\
\hline p-value Hausman test & & & $(0.000)$ \\
\hline Number of effective observations & 9,137 & 9,137 & 9,137 \\
\hline Number of individuals & 2,901 & 2,901 & 2,901 \\
\hline
\end{tabular}

Notes: Standard errors (in parentheses) should be interpreted as asymptotic lower bounds. Year dummies and selection correction terms (tobit residuals) are included though not reported. Mundlak terms are included in the pooled and RE models but redundant in the FE model. Actual working hours and the tobit residuals are treated as endogenous. Instruments used: age and age squared, other household income (log), house ownership, number of children, dummy variables indicating the age of the youngest child, bad health, marital status, and inverse Mills ratios calculated from FE logit estimates of the participation equation. The selection correction terms have significant effects in the RE and FE models, much less so in the Pooled estimates. 


\section{ANNEX}

Table 5 presents results of pooled, RE and FE estimation without correction for the selfselection of women into non-participation. Selection correction resulted in lower or very similar estimates in all three specifications and for all variables except temporary contract, education, east, and country of origin. In Pooled 2SLS and RE-2SLS, maternal leave penalties remain almost the same or slightly lower with the same time pattern in TABLE 4. However, the 2SLS- FE estimates without selection correction, presented in the last column of Table 5, differ substantially from their counterparts with selection correction. The actual working hours and full-time work experience variables turn insignificant, and the wage penalty due to maternal leave in the previous year decreases to $7 \%$ (from $10 \%$ in Table 4). However, the time pattern of the delayed effects of interruptions remains the same in the FE-2SLS models of Tables 4 and 5. 
Table 5: Wage equation without selection correction: Two stage least squares

\begin{tabular}{|c|c|c|c|}
\hline "Dependent variable: Log hourly wage & Pooled & RE model & FE model \\
\hline Actual working hours & -0.383 & -0.337 & 0.072 \\
\hline (hours divided by 40) & $(0.086)$ & $(0.089)$ & $(0.141)$ \\
\hline \multirow[t]{2}{*}{ Fraction of previous year in maternal leave } & -0.193 & -0.136 & -0.070 \\
\hline & $(0.037)$ & $(0.027)$ & $(0.030)$ \\
\hline \multirow[t]{2}{*}{ Fraction of year $\mathrm{t}-2$ spent in maternal leave } & -0.029 & -0.035 & -0.018 \\
\hline & $(0.030)$ & $(0.020)$ & $(0.021)$ \\
\hline \multirow[t]{2}{*}{ Fraction of year $\mathrm{t}-3$ spent in maternal leave } & 0.007 & 0.001 & -0.004 \\
\hline & $(0.027)$ & $(0.018)$ & $(0.019)$ \\
\hline \multirow[t]{2}{*}{ Fraction of year $\mathrm{t}-4$ spent in maternal leave } & -0.065 & -0.058 & -0.049 \\
\hline & $(0.025)$ & $(0.017)$ & $(0.017)$ \\
\hline \multirow[t]{2}{*}{ Fraction of year $\mathrm{t}-5$ spent in maternal leave } & -0.014 & -0.012 & -0.010 \\
\hline & $(0.021)$ & $(0.015)$ & $(0.016)$ \\
\hline \multirow{2}{*}{ Dummy if other interruptions in year $\mathrm{t}-1$} & -0.081 & -0.071 & -0.058 \\
\hline & $(0.017)$ & $(0.012)$ & $(0.013)$ \\
\hline \multirow[t]{2}{*}{ Dummy if other interruptions in year $\mathrm{t}-2$} & -0.052 & -0.051 & -0.038 \\
\hline & $(0.015)$ & $(0.011)$ & $(0.011)$ \\
\hline \multirow[t]{2}{*}{ Dummy if other interruptions in year $\mathrm{t}-3$} & -0.062 & -0.056 & -0.043 \\
\hline & $(0.015)$ & $(0.010)$ & $(0.011)$ \\
\hline \multirow{2}{*}{ Dummy if other interruptions in year $\mathrm{t}-4$} & -0.023 & -0.004 & 0.007 \\
\hline & $(0.014)$ & $(0.009)$ & $(0.010)$ \\
\hline \multirow[t]{2}{*}{ Dummy if other interruptions in year $t-5$} & -0.035 & -0.023 & -0.016 \\
\hline & $(0.013)$ & $(0.009)$ & $(0.010)$ \\
\hline \multirow[t]{2}{*}{ Number of children } & 0.015 & -0.009 & 0.001 \\
\hline & $(0.022)$ & $(0.017)$ & $(0.019)$ \\
\hline \multirow{2}{*}{ Education in institutionalised years } & 0.019 & 0.020 & 0.019 \\
\hline & $(0.005)$ & $(0.005)$ & $(0.005)$ \\
\hline \multirow{2}{*}{$\begin{array}{l}\text { Full-time work experience in years } \\
\text { (coefficient multiplied by 100) }\end{array}$} & 3.646 & 4.108 & 0.692 \\
\hline & $(0.278)$ & $(0.344)$ & $(1.316)$ \\
\hline \multirow{2}{*}{$\begin{array}{l}\text { Full-time work experience squared } \\
\text { (coefficient multiplied by } 10,000 \text { ) }\end{array}$} & -1.707 & -3.932 & -4.053 \\
\hline & $(0.491)$ & $(0.674)$ & (1.113) \\
\hline \multirow{2}{*}{$\begin{array}{l}\text { Part-time work experience in years } \\
\text { (coefficient multiplied by 100) }\end{array}$} & -0.079 & 0.549 & -1.614 \\
\hline & $(0.366)$ & $(0.319)$ & $(1.229)$ \\
\hline \multirow{2}{*}{$\begin{array}{l}\text { Unemployment experience in years } \\
\text { (coefficient multiplied by } 100 \text { ) }\end{array}$} & -1.261 & -2.727 & -6.859 \\
\hline & $(0.555)$ & $(0.700)$ & $(1.929)$ \\
\hline \multirow{2}{*}{$\begin{array}{l}\text { Temporary contract } \\
\text { (1 if temporary contract) }\end{array}$} & -0.062 & -0.085 & -0.109 \\
\hline & $(0.015)$ & $(0.013)$ & $(0.014)$ \\
\hline \multirow{2}{*}{$\begin{array}{l}\text { Training } \\
\text { ( } 1 \text { if trained })\end{array}$} & 0.062 & 0.009 & -0.010 \\
\hline & $(0.012)$ & $(0.009)$ & $(0.009)$ \\
\hline Mismatch & -0.148 & -.123 & -0.094 \\
\hline ( 1 if mismatch) & $(0.008)$ & $(0.009)$ & $(0.011)$ \\
\hline Firm tenure in years & 0.403 & 0.170 & -0.136 \\
\hline (coefficient multiplied by 100 ) & $(0.071)$ & $(0.079)$ & $(0.097)$ \\
\hline Firm size & 0.179 & 0.113 & 0.046 \\
\hline (1 if 200 workers or more) & $(0.008)$ & $(0.008)$ & $(0.011)$ \\
\hline East & -0.218 & -0.207 & -0.226 \\
\hline (1 if living in Eastern Germany) & $(0.011)$ & $(0.017)$ & $(0.052)$ \\
\hline Country of origin & -0.054 & -0.054 & \\
\hline (1 if non-Western) & $(0.012)$ & $(0.019)$ & \\
\hline Mundlak terms & Included & Included & Redundant \\
\hline Standard error individual effects & & 0.268 & 0.380 \\
\hline Standard error residual & 0.323 & 0.187 & 0.187 \\
\hline Autocorrelation of residuals & 0.730 & -0.053 & -0.084 \\
\hline & $(0.008)$ & $(0.013)$ & $(.013)$ \\
\hline Hausman Test RE vs FE chi-square(36) & & & 119.10 \\
\hline p-value Hausman test & & & $(0.000)$ \\
\hline Number of effective observations & 9,137 & 9,137 & 9,137 \\
\hline Number of individuals & 2,901 & 2,901 & 2,901 \\
\hline
\end{tabular}

Notes: Standard errors (in parentheses) should be interpreted as asymptotic lower bounds. Year dummies are included though not reported. Mundlak terms are included in the pooled and RE models but redundant in the FE model. Actual working hours are treated as endogenous. Instruments used: age and age squared, other household income (log), house ownership, number of children, dummy variables indicating the age of the youngest child, bad health and marital status. 